\title{
Primary Hydatid Cyst Mimicking Uterine Leiomyoma
}

\author{
Uterin Leiomyomu Taklit Eden Primer Hidatik Kist
}

Nermin Koç

Clinic of Pathology, İstanbul Zeynep Kamil Woman and Child Diseases Hospital, İstanbul, Turkey

\section{ABSTRACT}

Here, we present a rare case of a hydatid cyst in a 25-year-old woman, mimicking a uterine leiomyoma. The patient was admitted with lower abdominal pain and tenesmus, and ultrasonographic examination revealed a $10 \times 10 \mathrm{~cm}$ uniloculated mass with regular borders in the myometrium. The patient was operated with an initial diagnosis of a uterine leiomyoma with cystic degeneration, which was found to be hydatid cyst during frozen section and confirmed with the identification of protoscoleces during microscopy. This rare case report indicates the necessity of considering hydatid disease in the differential diagnosis of pelvic cysts, especially in endemic regions.

Keywords: Uterus, Echinococcus granulosus, hydatid cyst

Received: 26.11 .2015

Accepted: 03.02.2017

\section{Öz}

Burada, 25 yaşında bir kadın hastada saptanan, uterus leiomyomunu taklit eden, nadir görülen bir kist hidatik olgusu sunulmaktadır. Hastaneye alt bölgelerde karın ağrısı ve tenezm yakınmasıyla gelen hastanın ultrason ile yapılan incelemesinde myometrium sınırları dahilinde 10x10 cm'lik bir kitle tespit edilmiştir. Bunun üzerine kistik dejenerasyonla giden uterus leiomyomu ön tanısıyla operasyona alınan hastadan çıkartılan lezyonun yapılan "frozen" incelemesinde "Kist Hidatik" tanısı konulmuştur. Daha sonra bu tanı, mikroskobik incelemede protoskolekslerin görülmesiyle doğrulanmıştır. Bu oldukça nadir görülen olgu, özellikle kist hidatiğin endemik olduğu bölgelerde pelvik kitlelerin ayırıcı tanısında düşünülmesi gerektiğini işaret etmektedir.

Anahtar Kelimeler: Uterus, Echinococcus granulosus, hidatik kist

Geliş Tarihi: 26.11.2015

Kabul Tarihi: 03.02.2017

\section{INTRODUCTION}

Hydatid disease is a parasitic infection caused by the larval stages of Echinococcus granulosus, E. multilocularis, and E. vogeli. The disease remains a significant problem, especially in underdeveloped countries $(1,2)$. Definitive hosts mostly include dogs. The tapeworms grow into adults in the intestines of the host and are excreted with the feces. These eggs are ingested by sheep, pigs, cattle, and humans (the intermediate hosts). The eggs penetrate through the mucosa of the intestine, diffuse into the lymphatic and blood circulation, and are transported to other organs. The most frequent sites involved are the liver (75\%) and lungs (15\%), but it may be found in any part of the body, including the kidney, brain, heart, muscles, and bones $(1,2)$. The involve- ment of the genital tract is rare, with less common occurrence in the uterus (1). It may be confused with malignancies and other lesions of the affected organs. Here, we present a rare case of a primary hydatid cyst of the uterus mimicking a uterine leiomyoma.

\section{CASE REPORT}

A 25-year-old woman with lower abdominal pain and tenesmus was admitted to the Department of Obstetrics and Gynaecology at our hospital. On physical and gynecological examinations, no pathological findings were detected. Ultrasonography of the abdomen showed a $10 \times 10$ cmuniloculated mass with regular borders in the myometrium. Right and left adnexa, kidneys, liver, and

Address for Correspondence / Yazışma Adresi: Nermin Koç E.posta: nerminkoc@yahoo.com DOI: 10.5152/tpd.2017.4613

CCopyright 2017 Turkish Society for Parasitology - Available online at www.tparazitolderg.org

CTelif hakkı 2017 Türkiye Parazitoloji Derneği - Makale metnine www.tparazitolderg.org web sayfasından ulaşılabilir. 
spleen were all normal. All tumor markers, including carcinoembryonic antigen (CEA), CA 125, CA19-9, AFP, and B HCG were within normal ranges, as were the other biochemical and hematological parameters.According to these findings, a uterine leiomyoma with cystic degeneration was primarily considered, and the patient was operated in the Gynecology Surgery Department of our hospital. During the operation, a $10-\mathrm{cm}$ long, unilocular white cyst containing an opalescent fluid was detected inside the myometrium. Total cystectomy, including the surrounding myometrial tissue, was performed. The specimen was sent to the pathology labfor diagnosis with frozen section, which revealed the diagnosis of a hydatid cyst. Therefore, the abdominal cavity was washed thoroughly with hypertonic saline. Cut section of the specimen revealed a unilocular white cyst with a diameter of $10 \mathrm{~cm}$ (Figure 1). Microscopic examination showed scolices of Echinococcusgranulosus with an outer laminated hyaline membrane and an inner granular germinal layer, which confirmed the diagnosis of a hydatid cyst (Figure 2). The patient recovered after the surgery and used mebendazole for 6 months. Informed consent was taken from patient for this case report.

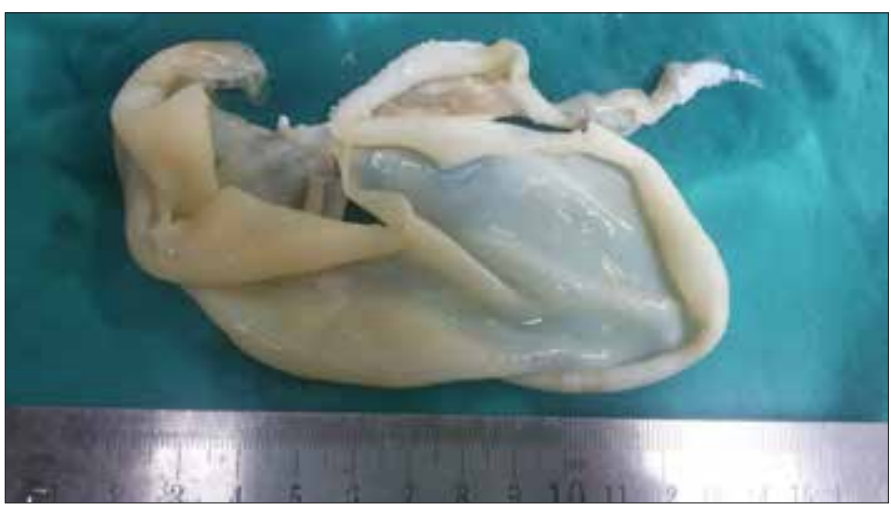

Figure 1. Gross appearance of the hydatid cyst

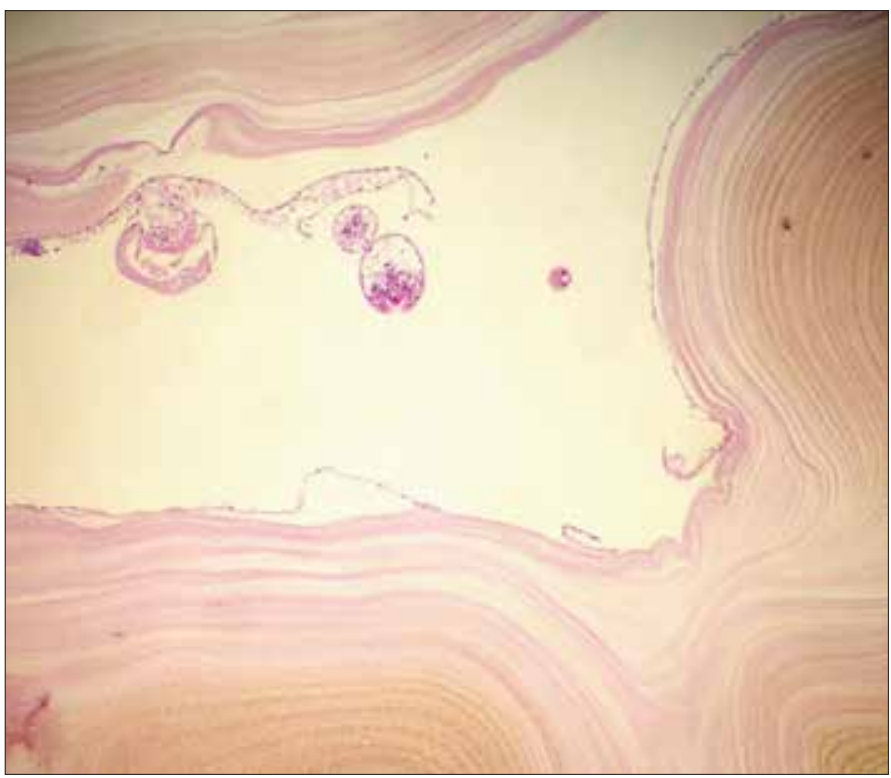

Figure 2. Histopathological findings: Laminated membrane and scolices $(H \& E \times 200)$

\section{DISCUSSION}

The common sites of hydatid cyst are the liver (75\%) and lungs (15\%). However, its unusual localizations, such as in the brain, heart, pericardium, kidney, intraperitoneum, retroperitoneum, bone, soft tissue, and breast, have already been demonstrated (3-6). Most of these locations are often part of a generalized disease.

Primary hydatid disease inside the pelvis is rather rare. Genital organs are reported to be the most affected areas in the pelvis; this can be attributed to their relatively rich bloodstream and true invasions from connective tissue of peritoneum of Douglas and suspensory ligaments $(3,7,8)$. The involvement of the ovary and fallopian tubes, uterine cavity, parametrium, and Douglas pouch have rarely been reported $(3,4,9)$.

The true diagnosis of a primary pelvic hydatid cyst is crucial due to its complications and the requirement of differential diagnosis. Possible complications of a pelvic hydatid disease may be urinary problems, rupture, or even obstructed labor. Generalized toxic reaction and secondary infections due to the rupture of the cyst are other common complications (3). Its differentiation from cancer and benign lesions is rather difficult and unexpected, when there is no history indicating the hydatid cyst. In the present case, the initial diagnosis was not hydatid disease but intrauterine leiomyoma with cystic degeneration. Radiography, ultrasonography, and computed tomography are used for the diagnosis of hydatid cysts. Serological tests are also applied and immunoglobulin G antibody detection by ELISA is commonly used, with a sensitivity of $95 \%$ (3). Ultrasonography was also the diagnostic method in the presented case here. The serological tests were not applied because there was no history of a hydatid cyst.

\section{CONCLUSION}

A very rare case of a primary hydatid cyst located in uterus was presented in this report. This case report indicates that the hydatid disease is still an important public health problem in certain underdeveloped countries. Our case report strongly suggests that the hydatid cyst should be considered in the differential diagnosis of cystic masses in the pelvis, particularly those in endemic regions.

Informed Consent: Informed consent was obtained from patients who participated in this study.

Peer-review: Externallypeer-reviewed.

Conflict of Interest: No conflict of interest was declared by the authors.

Financial Disclosure: The author declared that this study has received no financial support.

Hasta Onamı: Yazılı hasta onamı bu çalışmaya katılan hastalardan alınmıştır.

Hakem Değerlendirmesi: Dış Bağımsız.

Çıkar Çatışması: Yazar çıkar çatışması bildirmemiştir.

Finansal Destek: Yazarlar bu çalışma için finansal destek almadıklarını beyan etmişlerdir. 


\section{REFERENCES}

1. Schantz PM. Echinoccosis. In: Guerrant RL, walker DH, Weller PF, editors. Tropical Infections Disease: principles, pathogens \& practice. Philadelphia: churchill livingstone; 1999. pp. 1005-25.

2. Eckert J, Deplazes P. Biological, epidemiological, and clinical aspects of echinococcosis, a zoonosis of increasing concern. Clin Microbiol Rev 2004; 17: 107-35. [CrossRef]

3. Görgen $H$, Api M, Cetin A. Primary adnexial hydatid cyst mimicking ovarian tumor. J Turk Ger Gynecol Assoc 2009; 10: 232-4.

4. Nazari Z, Torabizadeh J. Primary hydatid cyst of the fallopian tube: A case report. Caspian J Intern Med 2014; 5: 179-81.
5. Behera PK, Satpathy S. Hydatidosis of female genital tract: a case report. Indian J Pathol Microbiol 2003; 46: 78-9.

6. Mushtaque M, Mir MF, Lone MA, Batt SH. Solitary subcutaneous gluteal hydatid cyst: a case report. East J Med 2010; 15: 76-9.

7. Terek MC, Ayhan C, Ulukuş M, Zekioğlu O, Ozkinay E, Erhan Y. Primary pelvic hydatid cyst. Arch Gynecol Obstet 2000; 264: 93-6. [CrossRef]

8. Peker K, Uluğ P, Naykı ÜA, Naykı C, Sayar I, Karakeçili F, et al. Primary uterine hydatid cyst: a case report. Turkiye Parazitol Derg 2013; 37: 302-4. [CrossRef]

9. Singh AP, Sikarwar S, Shrivastava BR, Gupta S, Sultana K. Primary hydatidosis of female genital tract: a case report. J Indian Med Assoc 2009; 107: 169-70. 